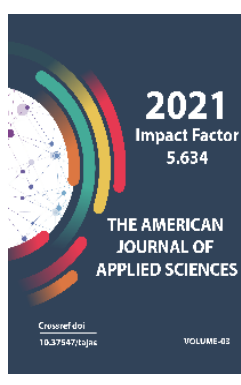

Journal Website: http://usajournalshub.c om/index,php/tajas

Copyright: Original content from this work may be used under the terms of the creative commons attributes 4.0 licence.

\section{The Role Of Small Business In The Management Of The Organized Structure}

\author{
Azimjon Urinboevich Adashev \\ Senior Lecturer, Namangan Engineering Construction Institute, Uzbekistan \\ Abdulkholik Mukhiddin Ugli Ismoilov \\ Student, Namangan Engineering Construction Institute, Uzbekistan
}

\title{
ABSTRACT
}

Small business is one of the most important sectors of the national economy. At the same time, small businesses play an important role not only in the national economy, but also in the social sphere. The article considers the nature of the organizational structure of the activities of small businesses and makes recommendations.

\section{KEYWORDS}

Small business, economy, sustainable growth, small business, structure, retail, sales function, control, marketing, financial affairs, divisional structure.

\section{INTRODUCTION}

From the first years of independence of Uzbekistan, great attention has been paid to the development of the legislative and legal framework, the organization of financial support, protection of the rights of entrepreneurs, training and retraining, development of market infrastructure for small businesses. 


\section{THE MAIN PART}

There is no best way to organize ${ }^{1}$. However, the organization's decision is based on direct principles that depend on many factors, including business size, market, product mix, competition, number of employees, goals, and available financial resources. Each small business entity must decide which organizational method is appropriate for their business. One of the organizational methods is the "Organizational Schedule" - a method of formal organization of business. ${ }^{2}$

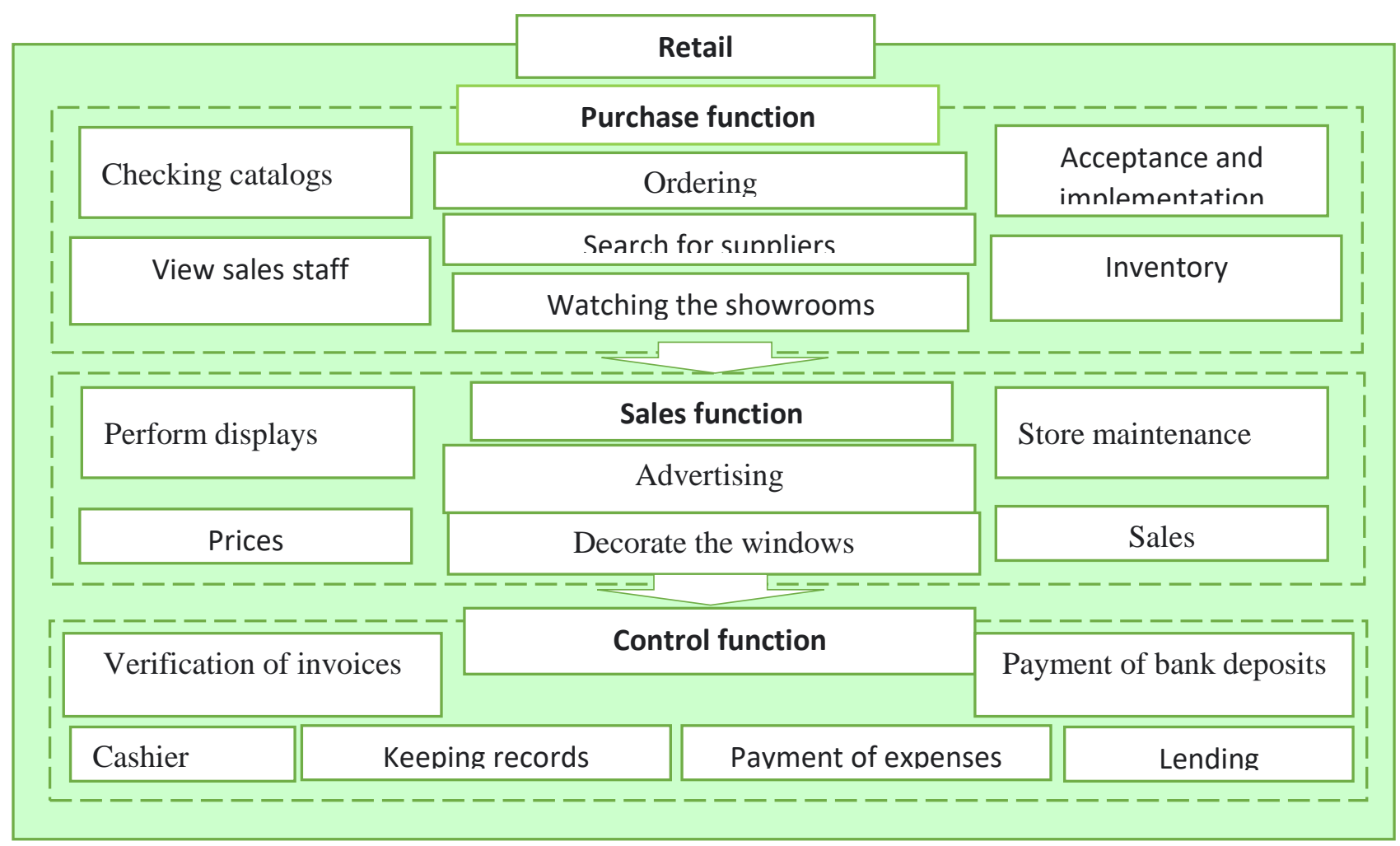

Figure 1. One-man small business organization model

Figure 1 shows the relationship and relative levels of the structure of the organization and its positions. This helps to organize the workplace along with setting the direction of management control for subordinates. Even a small one-person business can use some sort of organizational chart to see what functions

1 John Ivancevich, Thomas N. Duening Principles, Guidelines and Practices 2nd Edition. 2018 ISBN-13: 978-1592602827 need to be performed, which can help ensure that all the work needs to be done. In this regard, it is appropriate to cite the "Singleperson small business organization model", which reflects a simple organizational structure for a single-person retail business.

\footnotetext{
${ }^{2}$ William M. Pride, Robert J. Hughes Introduction to Business Paperback - South-Western Cengage Learning (January 1, 2008), 2008. 625 p.
} 
The Organizational Table offers the following advantages:

Effective communication of organizational, personnel and enterprise information;

Allow management to make decisions about resources, lay the groundwork for change management, and provide timely information throughout the organization;

The ability to be transparent about what is going to happen in the business and to predict the future;

Everyone in the organization is also divided with constant information about who manages what and who is accountable to whom.

Of course, there are some limitations in the "Organizational Schedule":

Defined positions are stable and flexible, often becoming obsolete as organizations go through stages of change and growth.

Does not help to understand what is happening in an informal organization;

Due to outsourcing, information technology, strategic alliances, and the network economy, firms cannot cope with changing boundaries.

At the initial stage, a small enterprise may not choose a formal organizational structure. However, for an enterprise to be successful, the organization must also exist without a schedule. Many small businesses find organizational charts useful because they help the owner or manager track the growth and change of the organizational structure. However, the real problem is to create an organizational chart that reflects the real situation. Small businesses have a clear advantage by creating an organizational chart that reflects the real situation, as their size allows for more flexibility and management.

Knowledge of organizational structures is important for both a small business that is already operating and for the early stages of a small business. Organizations change every day, so small business owners need to be flexible to change the structure that the situation requires over time, perhaps using an emergency approach.

An unforeseen situational approach to the structure of existing organizations suggests that there is no one structure that is best suited for each organization. Rather, this approach goes against the "best" structure for the organization because it fits the needs of the situation at the time. With regard to changes in organizational structures and their impact on management, it should be noted that if a small business employs less than fifteen people, there may be no need to worry too much about its organizational structure.

However, if the business plan envisages hiring more than fifteen people, it makes sense to have an organizational structure, as this will benefit the company owner, employees, investors and lenders.

Typically, small business entities have the same functional, divisional, and matrix structures as other large enterprises, the functional structure constitutes the business or purposeoriented business in the organization and is most easily recognized by single-function or goal-oriented departments. 


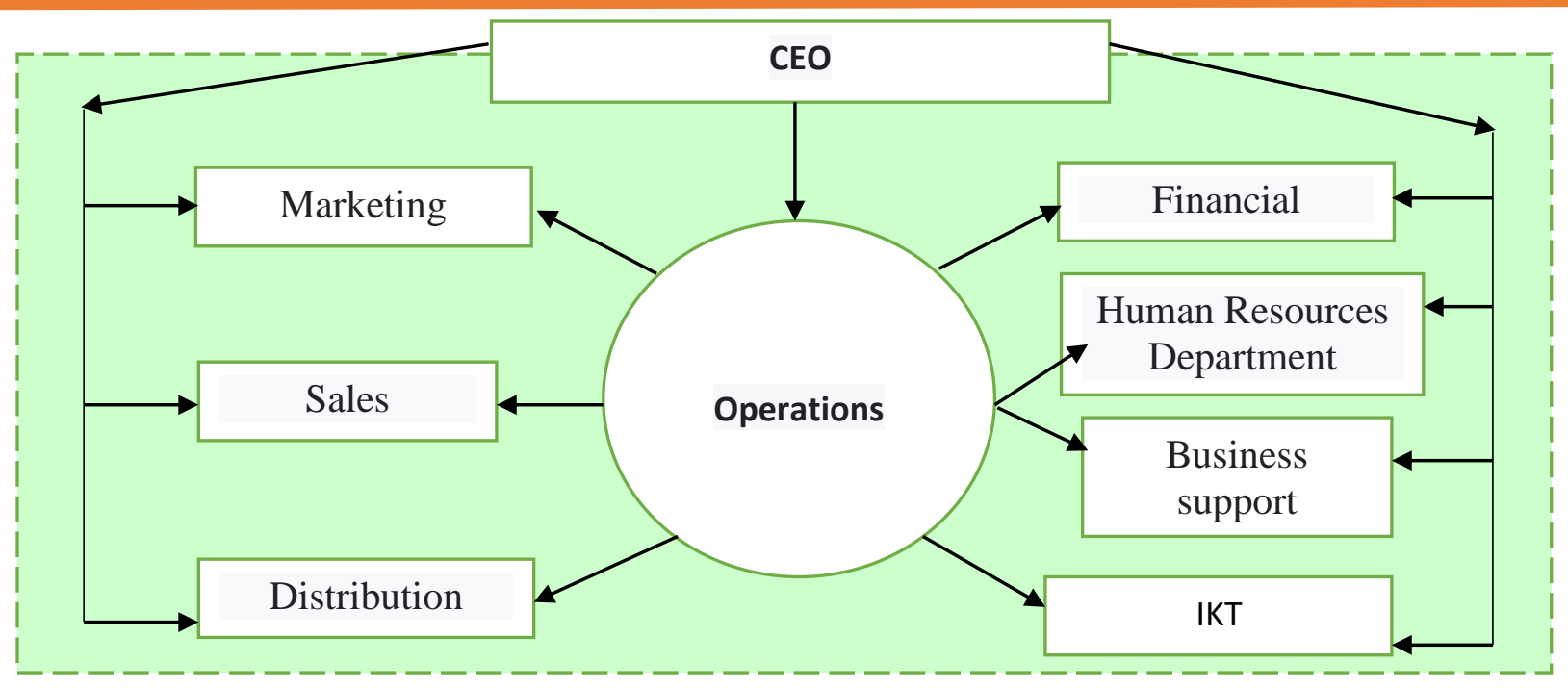

Figure 2 Management model of small business entities with a functional structure

The functional structure gives employees and their respective departments clear goals and their work objectives. People involved in accounting can focus on improving their knowledge and skills to do this job. Experience has shown that this structure works well for enterprises operating in a relatively stable environment. It should be noted that if the purpose and environment of the business requires coordination between departments and various conflicts arise, it can be observed that the functional structure leads to divisions between departments (Division structure).
The divisional structure can be thought of as a decentralized version of the functional structure. The organizational structure of a division is organized around the geographical, market or product and service groups of business activities. Each such subdivision includes a complete set of features. That is, each department has its own accounting activities, sales and marketing, engineering, manufacturing, and so on. Then each section will have its own functional section.

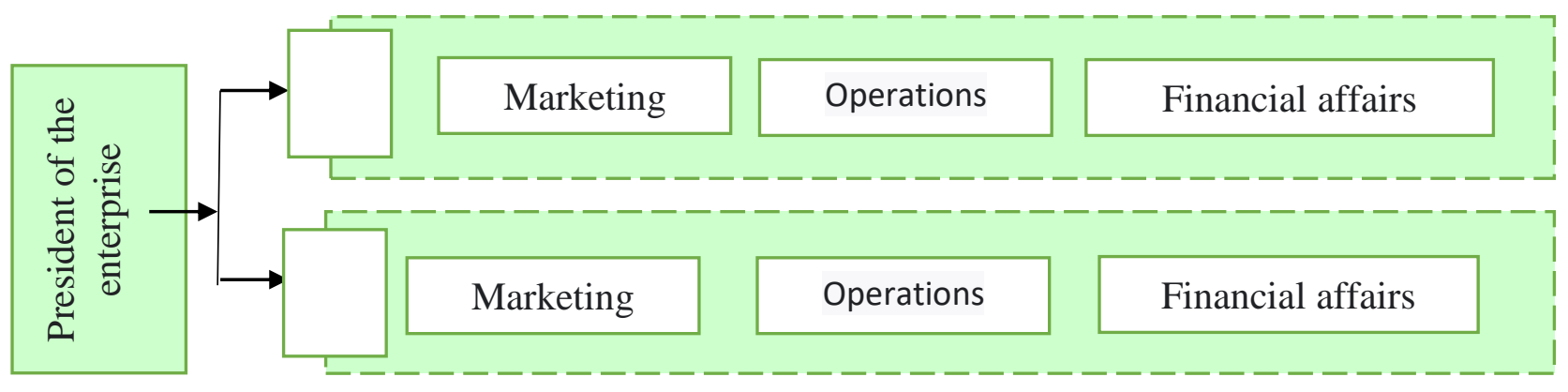

Figure 3 “Example of divisional structure" of small business entities 
The American Journal of Applied sciences (ISSN - 2689-0992)

Published: April 29, 2021 | Pages: 84-90

A small business entity in a division or divisional structure may perform well because it is focused on specific geographic areas, customers, or product manufacturing. This direction allows you to create a common culture that will increase the efficiency of the activity and help to better understand the high culture and the portfolio of the division. Of course, this structure also has some shortcomings.

Competitive divisions may resort to office policy rather than strategic thinking to guide decision-making, and individualism can lead to fragmentation to the point where it leads to inconsistency of purpose. As a small business begins to grow due to the diversity of its products, the geographical location of its markets, or its customer base, there is an evolution from a functional structure to a divisional structure. However, a significant increase in the activities of small businesses is needed before the divisional structure can be established.

The next structure is a matrix structure, which combines elements of functional and divisional structures, bringing together professionals from different areas of business to work on different projects in the short term.

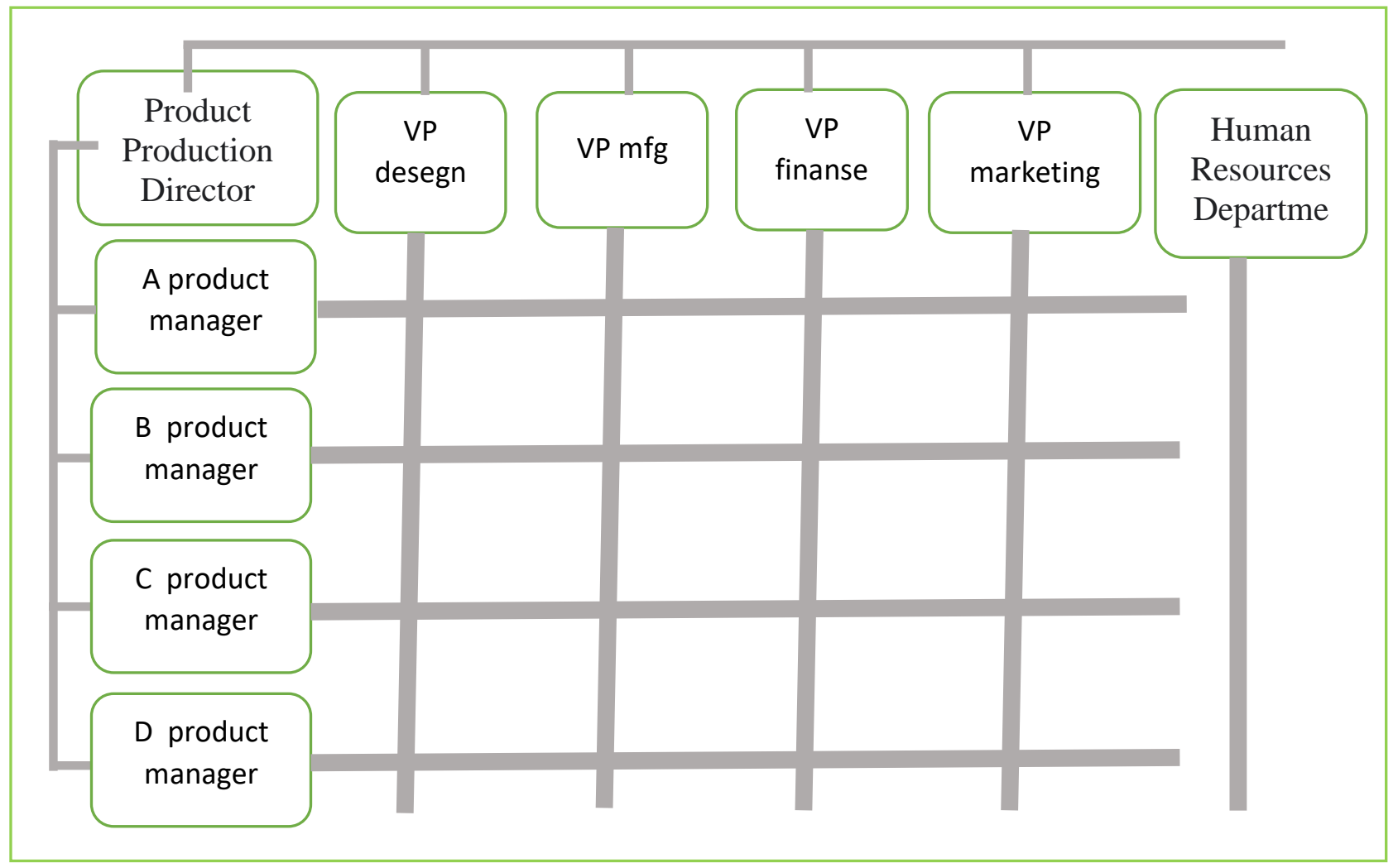

Figure 4. Small business entities in the matrix structure

In this, everyone in the project team reports to two bosses, namely the line manager and the project manager. The matrix structure, which is popular in high-tech, multinational enterprises, consulting and aerospace firms and hospitals, has several key factors in appointing professionals, such as rapid adaptation to environmental change, ability to focus 
The American Journal of Applied sciences

(ISSN - 2689-0992)

Published: April 29, 2021 | Pages: 84-90

resources on key products and challenges, creating an environment with high motivation and satisfaction for employees offers advantages.

To the shortcomings of the matrix structure violation of the principle of unity of command or "sole proprietor" due to the two directions of authority, responsibility and accountability staff confusion and frustration with reporting to two bosses; the emergence of strong struggles between first-line project managers; inconsistency in decision-making between groups, spending too much time; personal conflicts and undefined personal roles.

However, the shortcomings are distributed through many companies with multiple business divisions, operations in multiple countries, and multiple lines. Based on the research, it was found that the effective use of the matrix structure was their only choice.

\section{REFERENCES}

1. John Ivancevich, Thomas N. Duening Principles, Guidelines and Practices 2nd Edition. 2018 ISBN-13: 978-1592602827

2. William M. Pride, Robert J. Hughes Introduction to Business Paperback South-Western Cengage Learning (January 1, 2008), 2008. 625 p.

3. Адашев А. У., Арслонов Х. О. Мотивация персонала как функция менеджмента //Мировая наука. - 2019. - №. 1. - C. 34-37.

4. Urinboevich A. A. Principles of Effective Management of Small Business //International Journal of Progressive
Sciences and Technologies. - 2020. - T. 23. - №. 2. - C. 687-689.

5. Adashev A. U. Principles and laws of management //Экономика и социум. 2019. - №. 1-1. - C. 10-12.

6. Adashev A. U. Models of transition to market economy, their commonwealth and differences //Экономика и социум. - 2018. - №. 2. - C. 8-11.

7. Adashev A. U. Financial management as a system and mechanism of finance management //Экономика и социум. 2020. - №. 3. - C. 6-8.

8. Urinboevich, A. A. (2020). Directions for ensuring the sustainable development of industrial enterprises in the context of economic liberalization. International Engineering Journal For Research \& Development, 5(4), 3-3.

9. Адашев, А. Ў. (2017). Корхоналарда инновацион ривожланишининг таркибий асослари. Научное знание современности, (4), 8-12.

10. Адашев, А. У., \& Аскаралиев, А. (2017). Современные подходы к показателям и ценностям экономического развития. Теория и практика современной науки, (2), 28-30.

11. Adashev A. U. The content bases of the innovative development in companies //Высшая школа. - 2017. - №. 3. - С. 1011.

12. Urinboevich A. A. Directions for ensuring the sustainable development of industrial enterprises in the context of economic liberalization //International Engineering Journal For Research \& Development. - 2020. - T. 5. - №. 4. - C. 3-3.

13. AU Adashev Principles and laws of management- Экономика и социум, 2019. - №. 1. - C. 10-12. 
14. DS Kosimova, AU Adashev Directions to increase productivity competitiveness in industrial enterprises Economics and Innovative Technologies, 2019. №. 2. - C. 12.

15. Sobirovna D. K., O'rinboyevich A. A. Directions for increasing product competitiveness in industrial enterprises //Asian Journal of Multidimensional Research (AJMR). - 2019. - T. 8. - №. 7. C. 29-35.

16. АУ Адашев Значение малого бизнеса и частного редпринимательства в вопросах занятости . Молодой ученый, 2016 - №. 10. - C. 573-575.

17. Ismoilov A.M. Adashev A.U. The importance of organizational structure in small business management "Экономика и социум" 2021/1 21-25-с

18. AA Urinboevich Analysis of sustainable development of small business components of the republic of uzbekistan E-Conference Globe, 2021/2/26, 142-146-p.

19. АЎ Адашев Кичик бизнес субъектларида ишлаб чиқариш жараёнини ташкил этиш ва такомиллаштиришнинг назарий асослари Экономика и финансы (Узбекистан), 20204 (136)

20. АЎ Адашев Иқтисодиётни либераллаштириш шароитида саноатни ривожлантиришнинг устувор йуналишлари Экономика и финансы (Узбекистан), 20202 (134

21. Adashev Azimjon Urinboevich, Yuldashev Obidjon Orifjon ugli Theoretical fundamentals of organization and improvement of the production process in small business entities"Экономика и социум" 2021/1 $26-27-c$
22. М Ибрагимова Узбекская модель развития и место малого и частного предпринимательства в экономике Узбекистана Общество и экономика, 2018 33-38-c

23. IM Muxiddinovna Uzbekistan: Strategy from a Planned Economy to a Market 2017/2

24. $M M$

Ибрагимова

Предпринимательство в Узбекистане: малый и частный бизнес Научноаналитический журнал Наука и практика, 2017, 50-56 с 